\title{
Effects of mixed beech and hornbeam stands on soil properties and plant species diversity indices in Hyrcanian forests of Iran
}

\author{
Efecto de rodales mixtos de haya y carpe en las propiedades del suelo y en los \\ índices de diversidad de especies de plantas en bosques Hircanos, Irán \\ Simin Marefat', Javad Eshaghi Rad*1, and Ameneh Khanalizadeh'
}

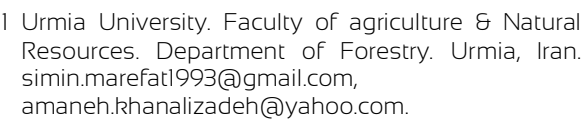

\begin{abstract}
Revealing the effect of mixed beech and hornbeam stands on herb layer diversity is essential for sustainable forestry and biodiversity conservation since little is known in Hyrcanian forests. So, we studied the effects of such stands on understory diversity and soil physico-chemical properties in Hyrcanian forests of Iran. Forty sampled plots were established by random systematic sampling method with a regular $100 \mathrm{~m} \times 200 \mathrm{~m}$ grid. At each sample point we recorded species identity and percent cover of each tree layer and herb layer species within plots of size $400 \mathrm{~m}^{2}(20 \mathrm{~m} \times 20 \mathrm{~m})$ and $100 \mathrm{~m}^{2}(10 \mathrm{~m}$ $\times 10 \mathrm{~m}$ ) respectively. Soil samples were taken from $0 \mathrm{~cm}-10 \mathrm{~cm}$ and $10 \mathrm{~cm}-30 \mathrm{~cm}$ soil depths. Cluster analysis was used to classify the samples based on the floristic composition data. Also detrended correspondence analysis (DCA) method was employed to assess the relationship between vegetation and environmental variables. There was no significant difference in terms of species richness, and diversity between mixed beech stands and hornbeam stands, but cluster analysis indicated that these stands were separated in two different groups based on herb layer species composition. DCA results showed that litter thickness, soil texture, total nitrogen, and organic carbon in the first layer were considered effective environmental variables in the distribution of sample plots in two stands. We observed that tree layer composition and soil characteristics were crucial contributors to variations of understory species composition which may be changed by forest management approaches over time. Tree layer composition and soil attributes can be considered effective factors for controlling and assessment of understory plant species composition. These findings could provide guidelines for conserving plant species diversity within any framework of sustainable forest management in Hyrcanian forests.
\end{abstract}

KEYWORDS: biodiversity conservation, herb layer diversity, species composition, species richness, sustainable forestry.

\section{RESUMEN}

Determinar el efecto de los rodales mixtos de haya y carpe sobre la diversidad del estrato herbáceo es esencial para la conservación de la biodiversidad y la silvicultura sostenible. De este tema se conoce poco en los bosques Hyrcanian y, por ello, en este trabajo se estudian los efectos de los rodales mixtos de hayas y carpe sobre la diversidad del sotobosque y las propiedades fisicoquímicas del suelo en los bosques Hircanos, en Irán. Se establecieron 40 parcelas mediante un muestreo sistemático aleatorio con una retícula regular de $100 \mathrm{~m} \times 200 \mathrm{~m}$. En cada punto de muestreo, se registró la identidad de las especies y el porcentaje de cobertura de los estratos herbáceo y arbóreo, dentro de parcelas $400 \mathrm{~m}^{2}(20 \mathrm{~m} \times 20 \mathrm{~m})$ y $100 \mathrm{~m}{ }^{2}(10 \mathrm{~m} \times 10 \mathrm{~m})$. Se tomaron muestras de suelo a profundidades de $0 \mathrm{~cm}-10 \mathrm{~cm}$ y $10 \mathrm{~cm}-30 \mathrm{~cm}$. Se utilizó el análisis de conglomerados para clasificar las muestras con base en los datos de composición florística. También se empleó el método de análisis de correspondencia sin tendencia (DCA) para evaluar la relación entre la vegetación y las variables ambientales. No hubo diferencias significativas en términos de riqueza de especies, uniformidad y diversidad entre los rodales mixtos de hayas y de carpe, pero el análisis de conglomerados indicó que estos rodales estaban separados en dos grupos diferentes, basado en la composición de especies por estrato. Los resultados del DCA mostraron que el espesor de la hojarasca, la textura del suelo, el nitrógeno total y el carbono orgánico en la primera capa se consideraron variables ambientales efectivas en la distribución de las parcelas de muestreo en dos rodales. Se observó que la composición del estrato arbóreo y las características del suelo contribuyeron de manera crucial a las variaciones de la composición de las especies del sotobosque que pueden cambiar con los enfoques de manejo forestal con el tiempo. Por lo tanto, la composición del estrato arbóreo y los atributos del suelo pueden considerarse factores efectivos para controlar y evaluar la composición de las especies de plantas del sotobosque. Además, estos hallazgos podrían proporcionar directrices para la conservación de la diversidad de especies vegetales dentro de cualquier marco de ordenamiento forestal sostenible en los bosques Hircanos.

PALABRAS CLAVE: conservación de la biodiversidad, diversidad del estrato herbáceo, composición de especies, riqueza de especies, manejo forestal sustentable. 


\section{INTRODUCTION}

Biological conservation is considered an important issue in sustainable forest management as a reaction to biodiversity loss (Verstraeten et al. 2013) since forest ecosystems have an essential role in the conservation of plant diversity. Plant species diversity has been recognized as an important determinant of the abundance and species richness in forest ecosystems (Barantal et al. 2019). The forest biodiversity not only responds to the changes in environmental conditions but is one of the important elements of ecosystem functions (Lucakc, 2017). Many studies have suggested that the stability of the plant community can be influenced by biodiversity where plant species richness has a strong correlation with plant species diversity in forests (Zeller \& Pretzsch, 2019; Versluijs, Roberge, Eggers, Boers, \& Hjältén, 2019; Barantal et al. 2019). In forest ecosystems, many factors (such as anthropogenic disturbances, physiographic factors and resources availability, etc.) influence the plant species diversity and its interaction with environmental factors (Kooijman \& Cammeraat, 2010; Jafari, Tabari, Hosseini, \& Kooch, 2014; Modabberi \& Minaie, 2014). Many researchers have extensively reported positive relationships between biodiversity and aboveground productivity in forest ecosystems (Ali, Yan, Chang, Cheng, \& Liu 2017; Prado-Junior et al. 2016; Wang et al. 2011; Zhang et al. 2017). On the other hand, soil characteristics are essential factors for driving plant species diversity in forest ecosystems (Petersen \& Luxton, 1982; Enright, Miller, \& Akhter, 2005; Hattenschwiler, 2005; Fujii et al. 2018). It has been reported that plant diversity has positive effects on the nutrient pools and ecosystem productivity (Midolo et al. 2018). Tree species have an essential role in protecting the soil Carbon (C) storage through the inputs of organic carbon and other nutrients via leaf litter decomposition (Prescott \& Vesterdal, 2013; Kerdraon, Drewer, Castro, Wallwork, \& Hall 2019). This process is an important driver for soil characteristics such as soil carbon content, nitrogen content, cation exchange capacity and $\mathrm{pH}$ in the forest topsoil layer (Augusto et al. 2015; Dawud et al. 2016; Bohara, Yadav, Dong, Cao, \& Hu,
2019). Xiao, Chen, Kumar, Chen, \& Guan, (2019) stated that tree species diversity affects the microenvironment conditions and litter decomposition rate as well as the chemical composition of the litter of overstory species which are an essential factor for the soil carbon and nitrogen content (Guendehou et al. 2014) and influencing the soil pH and nutrients (Eshaghi Rad, 2014; Lorenz \& Thiele-Bruhn, 2019). Also, Bartels and Chen (2013) concluded that total nitrogen content, exchangeable phosphorus, and cation exchange capacity had a significant positive correlation with the composition of tree species in the overstory stratum. In this context, a significant positive correlation was demonstrated between tree species diversity and soil carbon content by Gamfeldt et al. (2013). Furthermore, Modabberi and Minaie (2014) indicated that the correlation between herb layers as well as tree layers and the organic matter was positive. Elsewhere, Yang et al. (2017) reported that soil carbon and nitrogen content in the forest topsoil layer had a positive effect on the herbaceous species. Kooch, Samadzadeh, \& Hosseini (2017) demonstrated that tree species have a significant effect on litter quality and other soil physicochemical characteristics in the mixed stands. Bakhshandeh Navroud, Abrari Vajari and Kooch. (2018) illustrated a positive significant correlation between carbon content tree layer diversity in mature natural stands of easternforests, and deciduous broadleaved forests that are mainly located in the northern hemisphere (Mestre, Toro-Manríquez, Huertas-Herrera, Martínez-Pastur, \& Lencinas, 2017) where understory vegetation has a significant effect in these forests (Ampoorter, Baeten, Koricheva, Vanhellemont, \& Verheyen, 2014). Hyrcanian forests were one of the most important refuges for the temperate deciduous broadleaved forests during Pleistocene glaciations (Ramezani, Mohadjer, Knapp, Ahmadi, \& Joosten, 2008), they extend to the southern and south-western coasts of the Caspian Sea (Habashi \& Waez-Mousavi, 2017). In these forests, oriental beech (Fagus orientalis Lipsky.) stands and hornbeam (Carpinus betulus L.) stands represent the greatest volume (Adel, Pourbabaei, Omidi, \& Dey, 2013). 


\section{OBJECTIVES}

The aim of this investigation was to assess the effect of mixed beech and hornbeam stands on soil properties and plant species diversity in Hyrcanian forests which can be essential for forest ecologists and managers. Specifically, it was hypothesized that:

1) There is significant difference between mixed beech and hornbeam stands in terms of herb layer diversity indices.

2) Tree layer composition affects herb species composition and soil physico-chemical properties.

\section{MATERIALS AND METHODOS}

\section{Study area}

This investigation was conducted in Hyrcanian forests of northern Iran encompassing Dehga (mixed hornbeam stand) and Lakoobon (beech stand) districts (Fig. 1). Two compartments were selected in Dehga district located in the southern part of Tonekabon city. (Longitude: 50 52' 34"$50^{\circ} 75^{\prime} 15^{\prime \prime}$; Latitude: $\left.36^{\circ} 40^{\prime} 15^{\prime \prime}-36^{\circ} 44^{\prime} 25^{\prime \prime}\right)$. The average annual precipitation and temperature are $1188.6 \mathrm{~mm}$ and $15.2{ }^{\circ} \mathrm{C}$, respectively. The elevation ranges from $300 \mathrm{~m}$ to $400 \mathrm{~m}$. The dominant overstory species are hornbeam (Carpinus betulus L.), Persian ironwood (Parrotia persica (DC.) C.A. Mey.) Lilac persimmon (Diospyros lotus L.), Caucasian alder (Alnus subcordata C.A.Mey) and Caucasian wingnut (Pterocaria fraxinifolia (Lam.) spach in mixed hornbeam stands; Oriental beech (Fagus orientalis L.), hornbeam (Carpinus betulus L.), Persian maple (Acer velutinum Boiss.), Cappadocian maple (Acer cappadocicy Gled.) and Lime tree (Tillia begonifolia stev.) are dominant tree species in beech stands. Also, two compartments were selected in Lakobone district located in the western part of Nowshahr city. (Longitude: $51^{\circ} 16^{\prime} 15^{\prime \prime}-51^{\circ} 18^{\prime} 50^{\prime \prime}$ and Latitude: $36^{\circ} 36^{\prime}$ $\left.50^{\prime \prime}-36^{\circ} 40^{\prime}\right)$. The average annual precipitation and temperature are $1093 \mathrm{~mm}$ and $12.3{ }^{\circ} \mathrm{C}$, respectively. The elevation ranges from $800 \mathrm{~m}$ to $900 \mathrm{~m}$. In addition to Oriental beech (Fagus orientalis Lipsky), the dominant tree species are Persian maple (Acer velutinum Boiss.), Cappadocian maple (Acer cappadocicy Gled.), hornbeam (Carpinus betulus L.) and Lime tree (Tillia begonifolia stev.).

\section{Sampling strategy}

For this study, sampled plots were established by a regular $100 \mathrm{~m} \times 200 \mathrm{~m}$ grid (ten plots in each compartment). Percent cover of tree species was estimated by BraunBlanquet scale in $400 \mathrm{~m}^{2}$ plots. Also, in the centre of each main plot, a $100 \mathrm{~m}^{2}(10 \mathrm{~m} \times 10 \mathrm{~m})$ subplot was set up to record herb species. Soil samples were taken from $0 \mathrm{~cm}-$ $10 \mathrm{~cm}$ and $10 \mathrm{~cm}-30 \mathrm{~cm}$ soil depth. For laboratory analysis, the soil samples were air-dried and passed through a $2 \mathrm{~mm}$ sieve. Some phisico-chemical soil properties were measured for both depths, including: soil texture (sand, silt, and clay) by the Bouyoucos hydrometer method, soil $\mathrm{pH}$ by $\mathrm{pH}$ meter, total nitrogen $(\mathrm{N})$ using the Kjeldahl method and available phosphorus $(\mathrm{mg} / \mathrm{kg}$ ) by Olsen method. Further, exchangeable potassium $(\mathrm{mg} / \mathrm{kg})$ extracted by ammonium acetate $1 \mathrm{~N}$ was estimated using flame photometric method; organic carbon content $(\mathrm{C})$ was measured using Walkley and Black method.

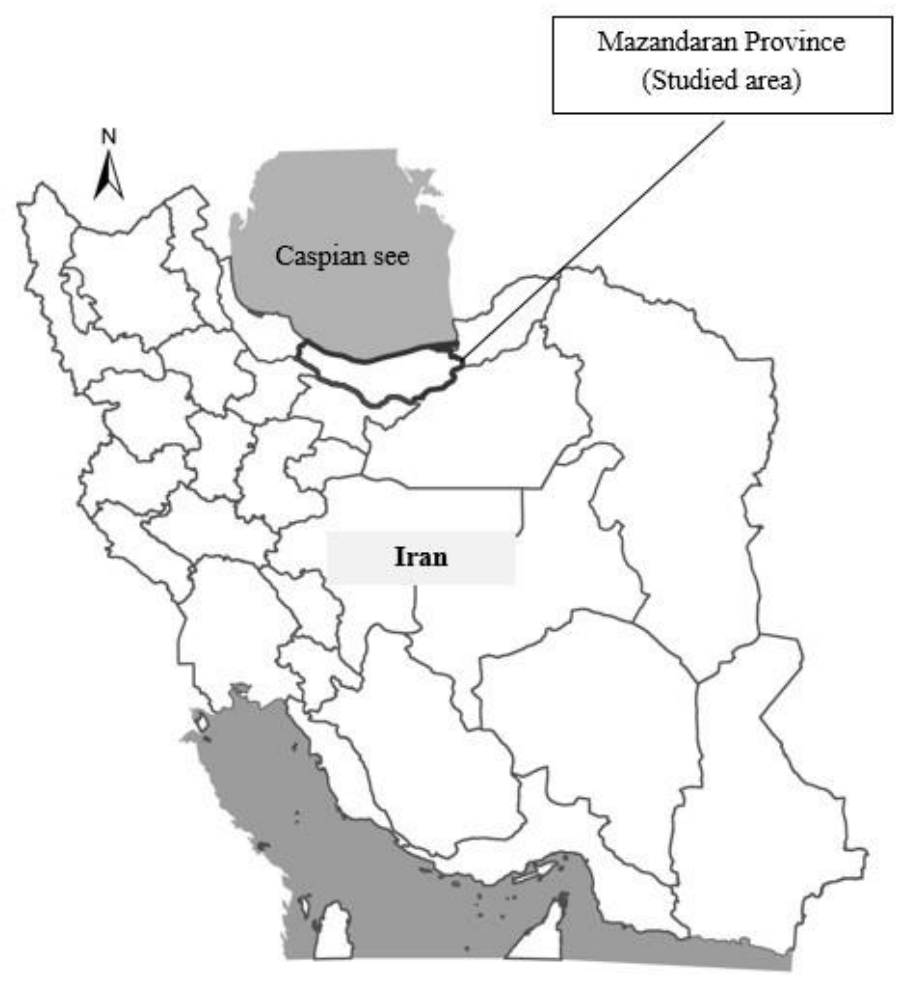

Figure 1. Location of studied area in Mazandaran Province, Northern Iran 


\section{Data analysis}

The Kolmogorov- Smirnov test was applied to check the data normality, and Levene's test was applied to test the homogeneity of the data variance. T-test (normally distributed data) and Mann-Whitney U-test (not normally distributed data) were utilized to test the significant differences in the species richness, diversity, and evenness indices as well as soil properties between the mixed beech and mixed hornbeam stands. This analysis was conducted using SPSS 18. We employed cluster analysis to classify of samples based on the floristic composition data using a Sørensen distance measurement and flexible beta linkage method (Eshaghi Rad, 2014). Also, the detrended correspondence analysis (DCA) method was applied to assess the relationship between vegetation and environmental variables. Pearson correlation analysis was employed to evaluate the correlation between sample plot scores of DCA axes and environmental variables as well as species diversity indices.
The plant species diversity was estimated using species richness as number of species, Shannon-Wiener evenness, Shannon-Wiener diversity $\left(\mathrm{H}^{\prime}\right)$ and Simpson diversity. PCORD software was used for calculating diversity indices and multivariate analysis.

\section{RESULTS}

Some of the frequent species were Acer velutinum, Carpinus betulus, Fagus orientalis, Hypericum androsaemum, Athyrium filixfemina, Asperula odorata and Solanum kieseritzkii in the mixed beech stands and Ilex aquifolium, Carpinus betulus, Parrotia persica, Asplenium adiantum-nigrum, Pteris cretica and Rubus byrcanus in the mixed hornbeam stands (Tables 1 and 2). The mean numbers of trees, basal areas, volume per hectare and DBH are provided in table 3 and 4 . Fagus orientalis had the maximum number of trees (176.25 ha-1), DBH (44.30 $\mathrm{cm})$, basal area $\left(33.68 \mathrm{~m}^{2} \mathrm{ha}^{-1}\right)$, and volume $\left(\mathrm{m}^{3} \mathrm{ha}^{-1}\right)$ in the mixed beech stand.Also, the highest number of trees, basal area and volume per hectare belonged to Carpinus betulus trees in the mixed hornbeam stand.

TABLE 1. Relative frequency (\%) of woody species in two stands (number of plots in which every species was recorded in relation to total number of plots*100).

\begin{tabular}{lcc}
\hline Species scientific name & Beech stand & Hornbeam stand \\
\hline Acercappadocicy Gled. & 20 & 5 \\
Acer velutinum Boiss. & 0 & 0 \\
Ilex aquifolium L. & 0 & 100 \\
Alnus subcordata C. A. Mey. & 0 & 50 \\
Carpinus betulus L. & 65 & 75 \\
Diospyrus lotus L. & 0 & 45 \\
Fagus orientalis Lipsky. & 100 & 0 \\
Fagus orientalis Lipsky & 0 & 35 \\
Parrotia persica (DC.) C.A. Mey. & 0 & 95 \\
Hypericum androsaemum L. & 70 & 35 \\
Laurocerasus officinalis Roemer & 25 & 0 \\
Danae racemosa (L.) Moench. & 10 & 0 \\
Ruscus hyrcanus Woron. & 15 & 60 \\
Rhumnus frangula L. & 10 & 0 \\
Tillia begoniifolia stev. & 10 & 0 \\
\hline
\end{tabular}


TABLE 2. Relative frequency (\%) of herbaceous species in two mixed stands (number of plots in which every species was recorded in relation to total number of plots* 100).

\begin{tabular}{|c|c|c|c|c|c|}
\hline Species scientific name & $\begin{array}{l}\text { Beech } \\
\text { stand }\end{array}$ & $\begin{array}{l}\text { Hornbeam } \\
\text { stand }\end{array}$ & Species scientific name & $\begin{array}{l}\text { Beech } \\
\text { stand }\end{array}$ & $\begin{array}{l}\text { Hornbeam } \\
\text { stand }\end{array}$ \\
\hline Acer cappadocicym Gled. & 15 & 5 & Lamium album $\mathrm{L}$. & 5 & 5 \\
\hline Acer velutinum Boiss. & 70 & 20 & Mespilus germanica $\mathrm{L}$. & 0 & 20 \\
\hline Asplenium adiantum-nigrum L. & 5 & 10 & .Oplismenus hirtellus (L.) P. Beauv & 40 & 70 \\
\hline Athyrium filix-femina (L) Roth & 85 & 50 & Polystichum aculeatum (L.) Roth & 55 & 5 \\
\hline Alnus subcordata C.A. Mey & 20 & 5 & Petasites hybridus (L.) P. Gaertn & 10 & $\mathrm{O}$ \\
\hline Asperula odorata L. & 95 & 0 & Parrotia persica. C.A. Mey & 0 & 65 \\
\hline Carpinus betulus L. & 0 & 65 & Prunella vulgaris $\mathrm{L}$. & 0 & 10 \\
\hline Carex divulsa Stokes. & 55 & 70 & Pteris cretica L. & 20 & 75 \\
\hline Carex remota $\mathrm{L}$. & 0 & 25 & Primula heterochroma Stapf. & 25 & 50 \\
\hline .Clinopodium umbrosum (M.B.) C. Koch & 10 & 35 & $\begin{array}{l}\text { Phyllitis scolopendrium (L.) } \\
\text { Newman }\end{array}$ & 30 & 20 \\
\hline Circaea lutetiana $\mathrm{L}$. & 25 & 55 & Rubus hyrcanus L. & 15 & 60 \\
\hline Cephalanthera caucasica Kranz. & 0 & 20 & $\begin{array}{l}\text { Symphyandra odontosepala } \\
\text { (Bioss.) Esfandiari }\end{array}$ & 10 & 0 \\
\hline Cratagegus monogvna Jacq. & 5 & 65 & Stachys sylvatica L. & 50 & 0 \\
\hline Dryopteris filix-mass (L.) Schott & 80 & 30 & Solanum kieseritzkii C.A. Mey & 100 & 45 \\
\hline Diospyrus lotus L. & 5 & 10 & Sanicula europaea L. & 20 & 10 \\
\hline Euphorbia amygdaloides L. & 85 & 70 & Tamus communis $\mathrm{L}$. & 30 & 0 \\
\hline Epimedium pinnatum Fisch. & 40 & 5 & Tillia begoniifolia stev. & 25 & 0 \\
\hline Fagus orientalis Lipsky. & 95 & 0 & Ulmus glabra Hudson. & 15 & 0 \\
\hline Festuca drymeia Mert. \& Koch & 25 & 0 & $\begin{array}{l}\text { Vincetoxicum scandens Sommier } \\
\text { \& Levier }\end{array}$ & 20 & 0 \\
\hline Fragaria vesca $\mathrm{L}$. & 15 & 75 & Viola odorata L. & 75 & 90 \\
\hline Gleditsia caspica Desf. & 0 & 20 & & & \\
\hline Geranium robertianum L. & 70 & 0 & & & \\
\hline Hedera helix $\mathrm{L}$. & 30 & 60 & & & \\
\hline
\end{tabular}

TABLE 3. Statistical parameters for dominant species in the mixed beech stand (Mean \pm standard deviation).

\begin{tabular}{ccccc}
\hline & Total stem number $/ \mathrm{ha}$ & $D B H(\mathrm{~cm})$ & Basal area $\left(\mathrm{m}^{2} / \mathrm{ha}\right)$ & Volume $\left(\mathrm{m}^{3} / \mathrm{ha}\right)$ \\
\hline Fagus orientalis & $176.25( \pm 16.67)$ & $44.30( \pm 3.67)$ & $33.68( \pm 4.28)$ & $464.69( \pm 75.02)$ \\
Carpinus betulus & $40.00( \pm 10.48)$ & $31.85( \pm 4.04)$ & $2.92( \pm 00.69)$ & $29.63( \pm 7.58)$ \\
Acer velutinum & $37.50( \pm 8.79)$ & $38.57( \pm 5.82)$ & $4.21( \pm 1.10)$ & $40.85( \pm 9.45)$ \\
Acer capadocicum & $6.25( \pm 4.00)$ & $31.00( \pm 7.55)$ & $0.48( \pm 00.30)$ & $5.76( \pm 3.79)$ \\
Tilia begonifolia & $3.75( \pm 2.74)$ & $17.50( \pm 3.50)$ & $0.11( \pm 00.9)$ & $1.19( \pm 1.11)$ \\
\hline
\end{tabular}


TABLE 4. Statistical parameters for dominant species in mixed hornbeam stand (Mean \pm standard deviation).

\begin{tabular}{ccccc}
\hline & Total stem number $\left(\mathrm{ha}^{-1}\right)$ & $D B H(\mathrm{~cm})$ & Basal area $\left(\mathrm{m}^{2} / \mathrm{ha}\right)$ & Volume $\left(\mathrm{m}^{3} / \mathrm{ha}\right)$ \\
\hline Carpinus betulus & $136.25( \pm 33.95)$ & $40.66( \pm 3.75)$ & $14.59( \pm 2.74)$ & $161.80( \pm 31.28)$ \\
Qurcus castanifolia & $13.75( \pm 6.14)$ & $70.50( \pm 12.62)$ & $4.78( \pm 1.73)$ & $57.64( \pm 22.91)$ \\
Alnus subcordata & $32.5( \pm 11.49)$ & $59.44( \pm 3.67)$ & $8.77( \pm 3.47)$ & $102.96( \pm 40.36)$ \\
Parrotia persica & $195.25( \pm 30.60)$ & $16.42( \pm 0.83)$ & $4.98( \pm 00.92)$ & $39.75( \pm 7.10)$ \\
Diospyrus lotus & $60.00( \pm 22.83)$ & $17.22( \pm 0.82)$ & $1.55( \pm 00.59)$ & $12.58( \pm 4.84)$ \\
Pterocaria fraxinifolia & $1.25( \pm 1.25)$ & $20.00( \pm 0.00)$ & $0.54( \pm 0.04)$ & $0.18( \pm 00.18)$ \\
\hline
\end{tabular}

TABLE 5. Species diversity indices in the studied stands (Mean \pm standard diviation).

\begin{tabular}{cccc}
\hline Diversity indices & Beech stand & Hornbeam stand & P-value \\
\hline Species richness & $19.15 \pm 3.51$ & $17.05 \pm 4.23$ & 0.096 \\
Shannon winner Evenness & $0.42 \pm 0.13$ & $0.46 \pm 0.09$ & 0.318 \\
Shannon- Winner $\left(\mathrm{H}^{\prime}\right)$ & $1.24 \pm 0.4$ & $1.28 \pm 0.26$ & 0.738 \\
Simpson index & $0.54 \pm 0.18$ & $0.60 \pm 0.12$ & 0.142 \\
\hline
\end{tabular}

There were no significant differences in plant species diversity indices between beech and hornbeam stands $(p$ value $<0.05$ based on Mann-Whitney test), (Table 5). Litter thicknesses and humus layers depth as well as the percentage of clay (in $0 \mathrm{~cm}-10 \mathrm{~cm}$ depth) were significantly higher in the beech stand compared to hornbeam stand (Table 6). Further, hornbeam stands had higher means in organic carbon and total nitrogen (in $0 \mathrm{~cm}-10 \mathrm{~cm}$ depth) along with percentage of sand in two depths compared to beech stands.

According to the diagram of cluster analysis, there are two distinct groups (Fig. 2). A total of 20 sampled plots of the mixed beech stand were considered as the first group and 20 sampled plots of the mixed hornbeam stand were regarded as the second group.

The result of DCA analysis clearly indicated that the thickness of the litter layers and humus, sand percent, total nitrogen, and organic carbon in the first layer could be considered as effective and powerful environmental variables in the distribution of sample plots in the mixed beech stand and the mixed hornbeam stand (Fig. 3). There was no significant correlation between soil organic carbon content, total nitrogen, carbon to nitrogen ratio, exchangeable potassium, exchangeable phosphorus, or $\mathrm{pH}$ of second layer and DCA axis (Table 7).

Pearson correlation analysis revealed that the species richness index was significantly negatively correlated with the percentage of silt $(\mathrm{R}=-0.346, \mathrm{P}<0.05)$ and positively correlated with percentage of clay $(\mathrm{R}=0.331)$ in first depth of soil $(0 \mathrm{~cm}-10 \mathrm{~cm})$. There were no significant correlations between soil thickness of the litter layer, thickness of the humus of layer, organic carbon content, total nitrogen, carbon to nitrogen ratio, exchangeable potassium, exchangeable phosphorus, sand percentage, $\mathrm{pH}$ of both layers and silt, clay or percentage in the second layer on all diversity indices (Table 8). 
Table 6. Soil variables in the studied stands (Mean \pm standard diviation).

\begin{tabular}{cccc}
\hline Soil variables & Beech stands & Hornbeam stand & $P$-value \\
\hline Litter (cm) & $3.16 \pm 0.59$ & $1.74 \pm 0.51$ & $0.00^{*}$ \\
Humus (cm) & $4.08 \pm 1.77$ & $0.55 \pm 1.78$ & $0.00^{*}$ \\
$\mathrm{pH} 1$ & $5.43 \pm 0.29$ & $5.44 \pm 0.36$ & 0.96 \\
$\mathrm{pH} 2$ & $5.64 \pm 0.44$ & $5.65 \pm 0.27$ & 0.93 \\
$\mathrm{OCl}(\%)$ & $2.69 \pm 0.92$ & $4.63 \pm 1.38$ & $0.00^{*}$ \\
$\mathrm{OC2} \%)$ & $1.11 \pm 0.57$ & $1.30 \pm 1.12$ & 0.429 \\
$\mathrm{~N} 1 \%)$ & $0.27 \pm 0.094$ & $0.46 \pm 0.13$ & $0.00^{*}$ \\
$\mathrm{~N} 2(\%)$ & $0.12 \pm 0.05$ & $0.13 \pm 0.11$ & 0.383 \\
$\mathrm{C} / \mathrm{N1}$ & $9.77 \pm 0.22$ & $9.88 \pm 0.12$ & 0.06 \\
$\mathrm{C} / \mathrm{N} 2$ & $9.23 \pm 0.52$ & $9.26 \pm 0.45$ & 0.87 \\
K1 (Mg/kg) & $179.1 \pm 62.48$ & $215 \pm 50.28$ & 0.05 \\
K2 (Mg/kg) & $174.30 \pm 90.19$ & $152.95 \pm 61.2$ & 0.698 \\
P1(Mg/kg) & $3.09 \pm 1.73$ & $5.18 \pm 2.60$ & 0.05 \\
P2(Mg/kg) & $2.27 \pm 2.88$ & $2.64 \pm 2.091$ & 0.91 \\
Clayl (\%) & $30.75 \pm 7.84$ & $20.85 \pm 3.34$ & $0.00^{*}$ \\
Clay2 (\%) & $40.80 \pm 8.53$ & $38.85 \pm 9.26$ & 0.49 \\
Silt1 (\%) & $53.50 \pm 7.11$ & $55.65 \pm 6.40$ & 0.32 \\
Silt2 (\%) & $46.15 \pm 7.13$ & $42.70 \pm 9.54$ & 0.231 \\
Sand1 (\%) & $15.75 \pm 3.02$ & $22.50 \pm 6.49$ & $0.00^{*}$ \\
Sand2 (\%) & $13.05 \pm 3.08$ & $18.45 \pm 7.97$ & $0.04^{*}$ \\
\hline
\end{tabular}

OC: organic carbon content, N: total nitrogen, K: potassium, P: phosphorus, l: soil depth at O cm - $10 \mathrm{~cm}$ (first layer), 2: soil depth at $10 \mathrm{~cm}-30 \mathrm{~cm}$ (second layer). * $p$ - value $<0.05$

TABLE 7. Pearson correlation between DCA Axes and soil properties.

\begin{tabular}{|c|c|c|}
\hline Soil variables & $D C A 1$ & $D C A 2$ \\
\hline Litter (cm) & $-0.826^{* *}$ & 0.266 \\
\hline Humus (cm) & $-0.659^{* *}$ & 0.221 \\
\hline $\mathrm{pH} 2$ & 0.013 & 0.133 \\
\hline $\mathrm{OCl}(\%)$ & $0.650^{* *}$ & 0.027 \\
\hline N2 (\%) & 0.134 & 0.153 \\
\hline $\mathrm{C} / \mathrm{N} 1$ & $0.335^{*}$ & -0.186 \\
\hline $\mathrm{C} / \mathrm{N} 2$ & 0.091 & 0.046 \\
\hline K1 (Mg/kg) & $0.356^{*}$ & 0.014 \\
\hline K2 (Mg/kg) & -0.094 & -0.037 \\
\hline Clay2 (\%) & -0.150 & $-0.370 *$ \\
\hline Silt1 (\%) & 0.096 & 0.079 \\
\hline Silt2 (\%) & -0.195 & $0.491^{* *}$ \\
\hline Sand1 (\%) & $0.652^{* *}$ & -0.109 \\
\hline
\end{tabular}




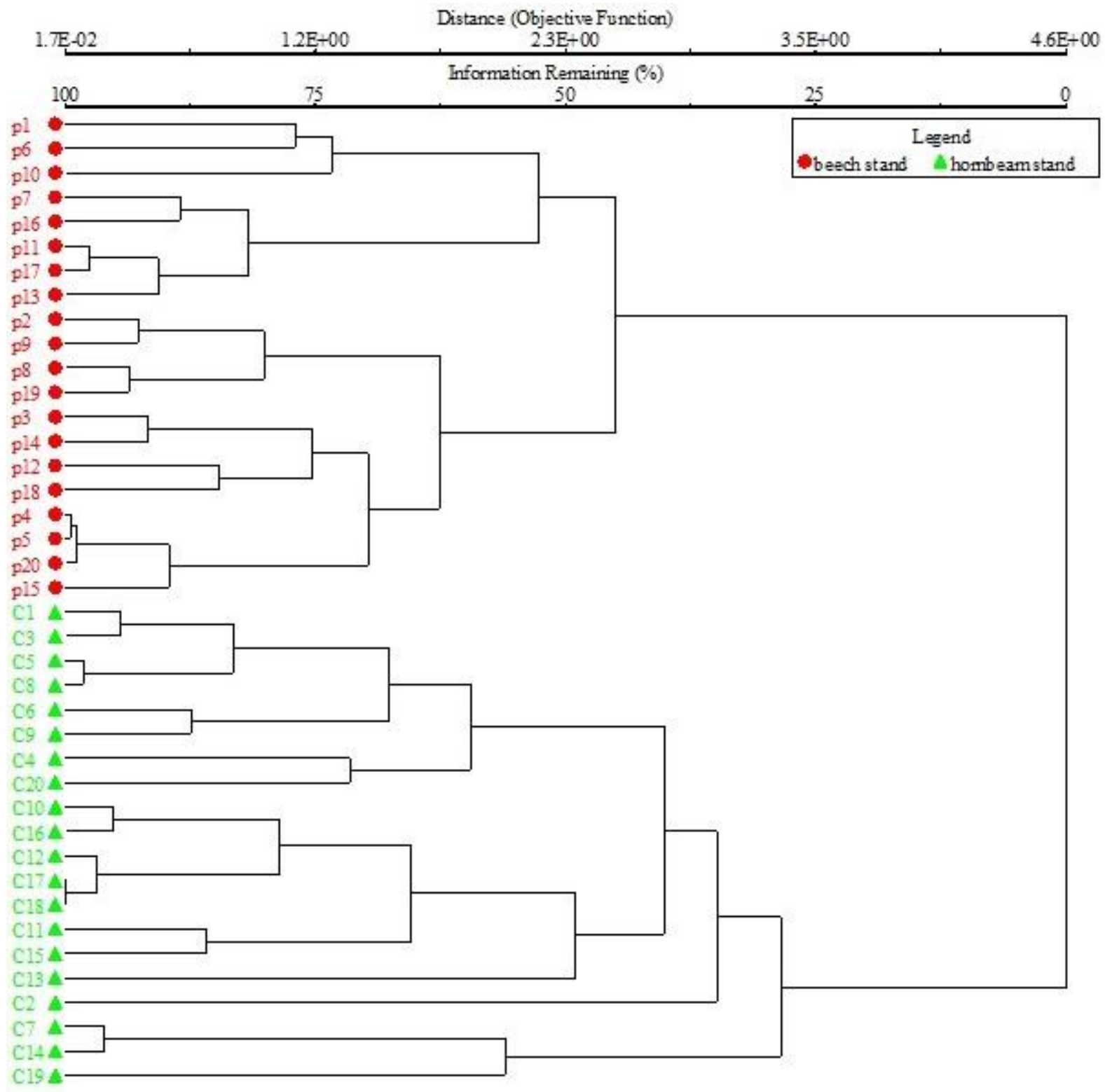

FIGURE 2. Diagram of cluster analysis on 40 sampled plots in the study area.

\section{DISCUSSION}

Our finding demonstrated that the overstory compositional dissimilarities in the mixed beech stand and mixed hornbeam stand had led to differences in the herb-layer vegetation, which is in line with the findings of Koojiman and Cammeraat (2010) in the Netherlands' forests. The composition of understory vegetation is influenced by tree species in the overstory stratum (Rawlik, Kasprowicz, \&
Jagodzinski, 2018; Dölle, Petritan, Biris, \& Petritan, 2017). Gilliam et al. (2007) stated that the composition of the overstory layer directly or indirectly affects the understory species by changing light availability, moisture and soil fertility. Generally, the shade of trees is an impressive feature in reducing the understory light-demanding species (Marcos, Marcos, Taboada, \& Tarrega, 2007; Marozas, Augustatitis, Armolaitis, Kliucius, \& Pilkauskas, 2013). It 
was proved that transmission of photosynthetically active rays (PAR) in the beech canopies was significantly lower than in canopies of other deciduous tree species. (Schmidt, 2005; Scolastri, Bricca, Cancellieri, \& Cutini, 2017). We confirmed that this barrier had caused the establishment and development of shade-tolerant species in the understory vegetation in the mixed beech stands. Some shade-tolerant species which are adapted to low light condition such as Mercurialis perennis L., Geranium robertianum L., Asperula odorata L. were mainly observed with a high frequency in the mixed beech stand. Indeed, the canopy cover of the beech species leads to low light infiltration into the forest floor, where the relative frequency of species such as Carex remota and Clinnopodium umbrosum has decreased with increase in the ratio of the beech species in overstory layer. On the other hand, Euphorbia amygdaloides and Festuca drymeia which were light demanding species mainly occurred with a high frequency in the mixed hornbeam stands.

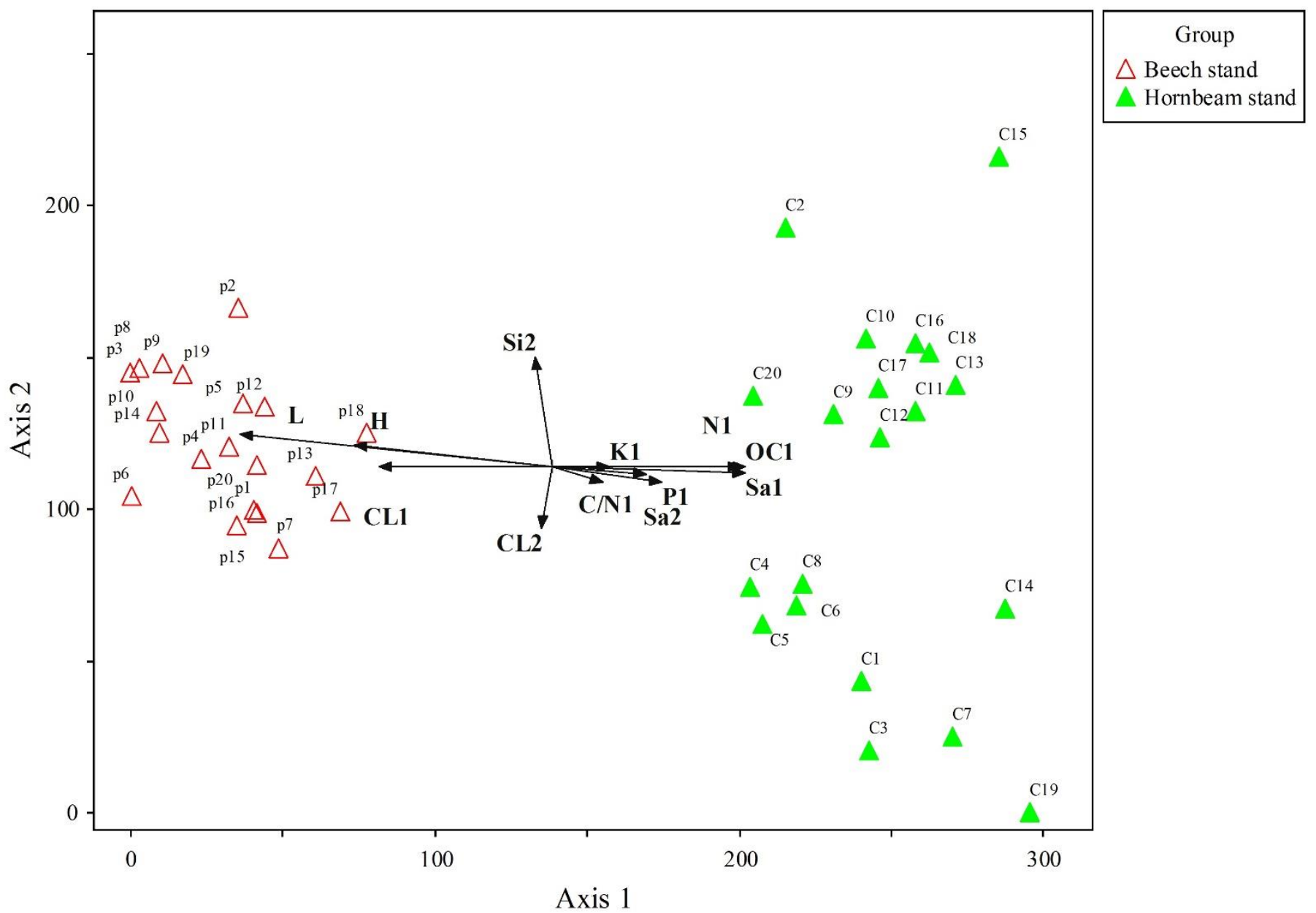

FIGURE 3. DCA ordination of herb layer species composition 
TABLE 8. The Pearson correlation between soil variables, and the species diversity indices in the studied stand.

\begin{tabular}{|c|c|c|c|c|}
\hline Soil variables & Species richness index & Evenness index & $\begin{array}{l}\text { Shannon- Winner (H') } \\
\text { index }\end{array}$ & Simpson index \\
\hline Litter (cm) & 0.150 & 0.109 & 0.172 & 0.009 \\
\hline Humus (cm) & 0.068 & -0.064 & -0.014 & -0.162 \\
\hline $\mathrm{pH}$ & 0.103 & 0.155 & 0.170 & 0.135 \\
\hline $\mathrm{pH} 2$ & 0.103 & 0.038 & 0.068 & 0.08 \\
\hline $\mathrm{OCl}(\%)$ & -0.203 & 0.152 & 0.044 & 0.158 \\
\hline OC2\%) & -0.284 & 0.032 & 0.036 & 0.039 \\
\hline $\mathrm{N} 1(\%)$ & -0.200 & 0.155 & 0.047 & 0.159 \\
\hline N2 (\%) & 0.016 & -0.029 & 0.037 & 0.038 \\
\hline $\mathrm{C} / \mathrm{N} 1$ & 0.086 & -0.106 & -0.110 & -0.053 \\
\hline $\mathrm{C} / \mathrm{N} 2$ & 0.045 & -0.025 & 0.011 & 0.001 \\
\hline $\mathrm{K} 1$ (Mg/kg) & 0.027 & 0.260 & 0.252 & 0.292 \\
\hline $\mathrm{K} 2(\mathrm{Mg} / \mathrm{kg})$ & 0.027 & 0.171 & 0.174 & 0.091 \\
\hline $\mathrm{Pl}(\mathrm{Mg} / \mathrm{kg})$ & -0.120 & 0.137 & 0.064 & 0.173 \\
\hline P2 (Mg/kg) & -0.190 & 0.165 & 0.218 & 0.202 \\
\hline Clayl (\%) & $0.331^{*}$ & -0.102 & 0.006 & -0.103 \\
\hline Clay2 (\%) & -0.042 & -0.092 & -0.101 & -0.072 \\
\hline Silt1 (\%) & $-0.346^{*}$ & 0.016 & -0.079 & -0.039 \\
\hline Silt2 (\%) & -0.005 & 0.152 & 0.155 & 0.100 \\
\hline Sandl (\%) & 0.051 & -0.073 & -0.064 & -0.032 \\
\hline Sand2 (\%) & -0.037 & 0.108 & 0.077 & 0.167 \\
\hline
\end{tabular}

OC: organic carbon content, N: total nitrogen, K: potassium, P: phosphorus, l: soil depth at O cm - $10 \mathrm{~cm}$ (first layer), 2: soil depth at $10 \mathrm{~cm}-30 \mathrm{~cm}$ (second layer). * $p$ - value $<0.05,{ }^{* *} p$ - value $<0.01$

In our study the thickness of the litter layer and humus, total soil nitrogen and organic carbon were the most important soil variables that caused the variations of the understory vegetation (Fig. 3). Kooch, Samadzadeh and Hosseini (2017) mentioned that structural differences in the tree canopy resulted in a difference in the quality of litter layer. The higher mean of the thickness of the litter layer in the beech stands is caused by of the slow process of chemical decomposition of the leaves of the beech Jacob, Viedenz, Polle, \& Thomas, 2010; Mölder, BernhardtRömerman, \& Schmidt 2008) which has been addressed in some studies. Kooijman and Cammeraan (2010) recorded the highest thickness of litter layer in beech stands. Amini, Rahmani, and Habashi (2011) reported that one of the main reasons for the slow decomposition litters of some species is the lack of leaves' nitrogen and phosphorus content for initiation of the activity of decomposition by microorganisms. Therefore, our findings suggested that in the mixed beech stand due to the low ratio of litter decomposition, release of nitrogen (Kooch, Sanji \& Tabari, 2019) was lower than in the mixed hornbeam stand. Dölle et al. (2017) confirmed that there was a positive significant correlation between the thickness of litter layer and beech dominance in the overstory stratum in the European beech stand. Bakhshandeh Navroud et al. (2018) found that an increase in the beech frequency resulted in diminished soil carbon and nitrogen content. The correlation results showed that there was no significant correlation between 
soil characteristics and diversity indices. Nevertheless, other researchers found that the biodiversity loss had a negative correlation with the amount of nitrogen, where higher nitrogen levels in the soil had a negative impact on local plant diversity (Midolo et al. 2018). The highest $\mathrm{pH}$ was recorded in the hornbeam stands in the research by Kooijman and Cammeraan (2010). A positive correlation between vegetation coverage and total soil phosphorus content was verified in Zhang et al. (2016) research. Vahder and Irmler (2012) indicated that the positive effect of beech dominance for mitigating the $\mathrm{pH}$ in the upper layer $(0-5 \mathrm{~cm})$ is greater than that of underlying layers in the beech dominated stands. Generally, the mixed beech stands in Hyrcanian temperate forests have a greater ratio of carbon content than pure oriental beech. Differences in soil fertility can explain the differences of variation in species composition of beech and mixed hornbeam stands. In other words, changes in soil variables can be correlated to different tree compositions in the site (Bakhshandeh Navroud et al. 2018). Therefore, each of these stands supports their indicator species.

\section{CONCLUSIONS}

We found that tree layer composition and soil attributes were crucial drivers in variations of understory species composition which may be altered by forest management approaches or natural disturbances over time. So, tree layer composition and soil attributes can be considered effective factors for controlling and assessment of understory plant species composition. The mixed beech and hornbeam stands differed in soil physico-chemical properties and herbaceous composition in Hyrcanian forests. These findings could enhance our knowledge about tree layerherb layer relationship (interaction) and provide guidelines to conserve plant species composition within any framework of sustainable forest management in Hyrcanian forests. For a complete analysis of the value for nature conservation we recommend (1) to include other taxa of plants and animals into the analysis, e.g. mammals, birds, fungi, and lichens (2) to include other criteria additionally to species richness and diversity into the evaluation for nature conservation, e.g. naturalness, rarity and endangerment, and restorability.

\section{ACKNOWLEDGMENTS}

The presented research was funded by the Iran National Science Foundation (No. 93043784).

\section{REFERENCES}

Adel, M., Pourbabaei, H., Omidi, A., \& Dey, C. (2013). Forest structure and woody plant species composition after a wildfire in beech forests in the north of Iran. Journal of Forestry Research, 24, 252-262. doi: 10.1007/s11676-012-0316-7

Ali, A., Yan, E. R., Chang, S. X., Cheng, J. Y., \& Liu, X. Y. (2017). Community-weighted mean of leaf traits and divergence of wood traits predict aboveground biomass in secondary subtropical forests. Science of the Total Environment, 574, 654-662. doi: 10.1016/j.scitotenv.2016.09.022

Amini, R., Rahmani, R., \& Habashi, H. (2011). Nitrogen, phosphorus and carbon dynamics of hornbeam leaf litter (Case study: District one, Shastkalate forest, Gorgan). Iranian Journal of Forest and Poplar Research, 19(1), 94-103.

Ampoorter, E., Baeten, L., Koricheva, J., Vanhellemont, M., \& Verheyen, K. (2014). Do diverse overstoreys induce diverse understoreys? Lessons learnt from an experimental-observational platform in Finland. Forest Ecology and Management, 318, 206-215. doi: 10.1016/j.foreco.2014.01.030

Augusto, L., De Schrijver, A., Vesterdal, L., Smolander, A., Prescott, C., \& Ranger, J. (2015). Influences of evergreen gymnosperm and deciduous angiosperm tree species on the functioning of temperate and boreal forest. Biological Reviens, 90(2), 444-466. doi: 10.1111/brv.12119

Barantal, S., Castagneyrol, B., Durka, W., Lason, G., Morath, S., \& Koricheva, J. (2019). Contrasting effects on tree species and genetic diversity on the leaf - miner communities associated with silver birch. Oecologia, 189(3), 678-697. doi : 10.1007/s00442-01904351-x

Bartels, S. F. \& Chen, H. Y. H. (2013). Interactions between overstorey and understorey vegetation along an overstorey compositional gradient. Journal of Vegetation Science, 24(3), 543-552. doi: 10.1111/j.1654-1103.2012.01479.x

Bakhshandeh-Navroud, B., Abrari Vajari, K., \& Kooch, Y. (2018). The interactions between tree-herb layer diversity and soil properties in the oriental beech (Fagus orientalis Lipsky.) stands in Hyrcanian forest. Environmental Monitoring and Assessment, 190(7), 1-10. doi: 10.1007/s10661-018-6809-x 
Bohara, M., Yadav, R. K. P., Dong, W., Cao, J., \& Hu, C. (2019). Nutrient and isotopic dynamics of litter decomposition from different land uses in naturally restoring Taihang Mountain, North China. Sustainability, 11(6), 1-19. doi:10.3390/su11061752

Dawud, S. M., Raulund-Rasmussen, K., Domisch, T., Fin`er, L., Jaroszewic, B., \& Vesterdal, L. (2016). Is tree species diversity or species identity the more important driver of soil carbon stocks, $\mathrm{C} / \mathrm{N}$ ratio and pH?. Ecosystems, 19 (4), 645-660. doi: 10.1007/s10021-016-9958-1

Dölle, M., Petritan, M. A., Biris, A. L., \& Petritan, C. I. (2017). Relations between tree canopy composition and understory vegetation in European beech-sessile oak old growth forest in Western Romania. Biologia, 72(12), 1422-1430. doi: 10.1515/biolog-20170165

Enright, N. J., Miller, B. P., \& Akhter, R. (2005). Desert vegetation and vegetation-environment relationships in Kirthar National Park, Sindh, Pakistan. Journal of Arid Environments, 61(3), 397-41. doi: 10.1016/j.jaridenv.2004.09.009

Eshaghi Rad, J. (2014). Variations of understory vegetation composition and diversity in pure and mixed beech stands (Case Study: Kheyrud Forest- Noshahr). Iranian Journal of Forest, 6(1), 75-86.

Fujii, K., Shibata, M., Kitajima, K., Ichie, T., Kitayama, K., \& Turner, B. (2018). Plant-soil interactions maintain biodiversity and functions of tropical forest ecosystems. Ecological Research, 33, 149-160. doi: 10.1007/s11284-017-1511-y

Gamfeldt, L., Snall, T., Bagci, R., Jonsson, M., Gustafsson, L., Kjellander, P \& Mikusin`ski, G. (2013). Higher levels of multiple ecosystem services are found in forests with more tree species. Nature Communications, 4, 1-8. doi: 10.1038/ncomms2328

Gilliam, F. S. (2007). The ecological significance of the herbaceous layer in temperate forest ecosystems. BioScience, 75(10), 845-858. doi: 10.1641/B571007

Guendehou, G.S., Liski, J., Tuomi, M., Moudachirou, M., Sinsin, B., \& Makipaa, R. (2014). Decomposition and changes in chemical composition of leaf litter of five dominant tree species in a West African tropical forest. Tropical Ecology, 55(2), 207-220.

Habashi, H. \& Waez-Mousavi, S.M. (2017). Single-tree selection system effects on forest soil macrofauna biodiversity in mixed oriental beech stands. Applied Soil Ecology, 123, 441-446. doi:10.1016/j.apsoil.2017.09.023

Hattenschwiler, S. (2005). Effects of Tree Species Diversity on Litter Quality and Decomposition. Forest Diversity and Function, 176, 149164. doi: 10.1007/3-540-26599-6_8
Jacob, M., Viedenz, K., Polle, A., \& Thomas, F. M. (2010). Leaf litter decomposition in temperate deciduous forest stands with a decreasing fraction of beech (Fagus sylvatica). Oecologia, 164, 10831094. doi: 10.1007/s00442-010-1699-9

Jafari, J., Tabari, M., Hosseini, S.M., \& Kooch, Y. (2014). Effect of soil properties on plant diversity of ecological groups in the reserved forest of Northern Khorasan. Journal of Plant Biology, 28(1), 79-90.

Kerdraon, D., Drewer, J., Castro, B., Wallwork, A., \& Hall, J. (2019). Litter Traits of Native and Non-Native Tropical Trees Influence Soil Carbon Dynamics in Timber Plantations in Panama. Forests, 10 (3), 1-17. doi: 10.3390/f10030209

Kooch, Y., Samadzadeh, B., \& Hosseini, S M. (2017). The effects of broad-leaved tree species on litter quality and soil properties in a plain forest stand. Catena, 150, 223-229. doi: 10.1016/j.catena.2016.11.023

Kooch, Y., Sanji, R., \& Tabari, M. (2019). The effect of vegetation change in $\mathrm{C}$ and $\mathrm{N}$ contents in litter and soil organic fractions of a Northern Iran temperate forest. Catena, 178, 32-39. doi: 10.1016/j.catena.2019.03.009

Kooijman, A. K. \& Cammeraat, E. (2010). Biological control of beech and hornbeam affects species richness via changes in the organic layer, PH and soil moisture characteristics. Functional Ecology, 24(2), 469-477. doi: 10.1111/j.1365-2435.2009.01640.x

Lorenz, M. \& Thiele-Bruhn, S. (2019). Tree species affect soil organic matter stocks and stoichiometry in interaction with soil microbiota. Geoderma, 353, 35-46. doi: 10.1016/j.geoderma.2019.06.021

Lukac, M. (2017). Soil biodiversity and environmental change in European Forests. Central European Forestry Journal, 63(2), 59-65. doi: 10.1515/forj-2017-0010

Marcos, J. A., Marcos, E., Taboada, A., \& Tarrega, R. (2007). Comparsion of community structure and soil characteristics in different aged Pinus sylvestris plantations and a natural pine forest, Forest Ecology and Management, 274, 35-42. doi: 10.1016/j.foreco.2007.04.022

Marozas, V., Augustatitis, A., Armolaitis, K., Kliucius, A., \& Pilkauskas, M. (2013). Effects of planted European beech on the understory in Scots pine forests of Lithuania. Biogeosciences and Forestry, 7(1), 12-18. doi: 10.3832/ifor0695-007

Mestre, L., Toro-Manríquez, M., Huertas-Herrera, A., Martínez-Pastur, G., \& Lencinas, M. V. (2017). The influence of canopy-layer composition on understory plant diversity in Southern temperate forests. Forest Ecosystems, 4(6), 1-13. doi: 10.1186/s40663-0170093-z 
Midolo, G., Alkemade, R., Schipper, A. M., Benitez-Lopez, A., Perring, M. P., \& De vries, W. (2018). Impacts of nitrogen addition on plant species richness and abundance: A global meta-analysis. Global ecology and Biogeography, 28(3), 398- 413. doi: $10.1111 /$ geb.12856

Modabberi, A. \& Minaie, H. (2014). Biodiversity and plant species richness study in relation to physiographic factors and soil physicochemical properties (KhoramAbad, Khankamandar region). Environmental Science and Engineering, 1(4), 19-27.

Mölder, A., Bernhardt-Römerman, M., \& Schmidt, W. (2008). Herblayer diversity in deciduous forests: Raised by tree richness or beaten by beech?. Forest Ecology and Management, 256, 272-281. doi:10.1016/J. foreco.2008.04.012

Petersen, H. \& Luxton, M. (1892). A comparative analysis of soil fauna populations and their role in decomposition processes. OIKOS, 39, 287-388.

Prado-Junior, J. A., Schiavini, I., Vale, V. S., Arantes, C. S., Sande, M. T., Lohbeck, M., \& Poorter, L. (2016). Conservative species drive biomass productivity in tropical dry forests. Journal of Ecology, 104(3), 817-827. doi: 10.1111/1365-2745.12543

Prescott, C. E. \& Vesterdal, L. (2013). Tree species effects on soils in temperate and boreal forests: Emerging themes and research needs. Forest Ecology and Management, 309, 1-3. doi: 10.1016/j.foreco.2013.06.042

Ramezani, E., Mohadjer, M. R., Knapp, H. D., Ahmadi, H., \& Joosten, H. (2008). The late-Holocene vegetation history of the Central Caspian (Hyrcanian) forests of northern Iran. Holocene, 18(2), 307-321. doi: 10.1177/0959683607086768

Rawlik, M., Kasprowicz, M., \& Jagodzinski, A. M. (2018). Differentiation of herb layer vascular flora in reclaimed areas depends on the species composition of forest stands. Forest Ecology and Management, 409, 541-551. doi: 10.1016/j.foreco.2017.11.055

Schmidt, W. (2005). Herb layer species as indicators of biodiversity of managed and unmanaged beech forest. Forest Snow Landscape Research, 79(1), 111-125.

Scolastri, A., Bricca, A., Cancellieri, L., \& Cutini, M. (2017). Understory functional response to different management strategies in Mediterranean beech forest (Central Apennines, Italy). Forest Ecology and Management, 400, 665-676. doi: 10.1016/j.foreco.2017.06.049

Vahder, S. \& Irmler, U. (2012). Effect of pure and multi species beech (Fagus sylvatica) stands on soil characteristics and earthworm in two northern German forests. European journal of soil Biology, 51, 45-50. doi: 10.1016/j.ejsobi.2012.03.008
Versluijs, M., Roberge, J. M., Eggers, S., Boers, J., \& Hjältén, J. (2019). Ecological restoration for biodiversity improves habitat quality for an insectivorous passerine in boreal forest. Biological Conservation, 237, 90-96. doi: 10.1016/j.biocon.2019.06.025

Verstraeten, G., Baeten, L., De Frenne, P., Vanhellemont, M., Thomaes, A., Boonen, W., Muys, B., \& Verheyen, K. (2013). Understory vegetation shifts following the conversion of temperate deciduous forest to spruce plantation. Forest Ecology and Management, 289, 363-370. doi: 10.1016/j.foreco.2012.10.049

Wang, G., Li, H., An, M., Ni, J., Ji, S., \& Wang, J. (2011). A regional-scale consideration of the effects of species richness on above-ground biomass in temperate natural grasslands of China. Journal of Vegetation Science, 22(3), 414-424. doi: 10.1111/j.16541103.2011.01279.x

Xiao, W., Chen, H., Kumar, P., Chen, Ch., \& Guan, Q. (2019). Multiple interactions between tree composition and diversity and microbial diversity underly litter decomposition. Geoderma, 341, 161-171. doi: 10.1016/j.geoderma.2019.01.045

Yang, B., Li, Y., Ding, B., Both, S., Erfmeier, A., Hardtle, W., Ma, K., Schmid, B., Scholten, Th., \& Seidler, G. (2017). Impact of tree diversity and environmental conditions on the survival of shrub species in a forest biodiversity experiment in subtropical china. Journal of Plant Ecology, 10(1), 179-189. doi: 10.1093/jpe/rtw099

Zeller, L. \& Pretzsch, H. (2019). Effect of forest structure on stand productivity in Central European forests depends on developmental stage and tree species diversity. Forest Ecology and Management, 434, 193-204. doi: 10.1016/j.foreco.2018.12.024

Zhang, Q., Buyantuev, A., Li, F.Y., Jiang, L., Niu, J., Ding, Y., Kang, S., \& Ma, W. (2017). Functional dominance rather than taxonomic diversity and functional diversity mainly affect community aboveground biomass in the Inner Mongolia grassland. Ecology and Evolution, 7(5), 1605-1615. doi: 10.1002/ece3.2778

Zhang, Y., Zhang, C., Wang, Z., Chen, Y., Gang, C., An, R., \& Li, J. (2016). Vegetation dynamics and its driving forces from climate change and human activities in the Three-River Source Region, China from 1982 to 2012. Science of the Total Environment, 563, 210220. doi: 10.1016/j.scitotenv.2016.03.223

Received: 11 August 2019

Accepted: 04 February 2020

Published: 17 November 2020 
This paper must be cited as:

Marefat, S., Eshaghi R., J., \& Khanalizadeh, A. (2020). Effects of mixed beech and hornbeam stands on soil properties and plant species diversity indices in Hyrcanian forests of Iran. Madera y Bosques, 26(3), e2632015. doi:10.21829/myb.2020.2632015
Madera y Bosques by Instituto de Ecología, A.C. is distributed under a Creative Commons Licence Attribution-NonCommercial-ShareAlike 4.0 International. 